\title{
Palliative Care in Primary and Metastatic Brain Tumors
}

\section{Primer ve Metastazik Beyin Tümörlerinde Palyatif Bakım}

\author{
Gülhan Sarıçam', @Kadriye Kahveci² \\ 'Pursaklar State Hospital, Department of Neurology Clinic, Ankara, Turkey \\ ${ }^{2}$ Ankara City Hospital, Department of Anesthesology and Reanimation, Turkey
}

\begin{abstract}
Introduction: Early palliative care interventions and structured advance care planning can improve symptom control and quality of life in patients with a brain tumor. In this study, we aimed to investigate symptoms, hospital discharge conditions, and the length of stay of patients with primary and metastatic brain tumors in our palliative care center (PCC).
\end{abstract}

Material and Method: Ninety-one patients; who had been followed-up in the PCC with the diagnosis of a primary or metastatic brain tumor were included in this retrospective study. Demographic characteristics, Glasgow Coma Scale (GCS) scores, Karnofsky Performance Scale (KPS) scores, hospital discharge status, and symptoms of the patients included in the study were compared.

Results: The mean age of the patients was 60.67 years; $59.3 \%$ were male, and the mean length of hospital stay was 29.26 days. The rates of PEG, tracheostomy, seizures, and paresis symptoms were significantly higher in patients with a primary brain tumor $(p<0.05)$. The rates of death in the hospital were significantly higher in patients with metastatic tumors and low GCS scores $(p=0.032$ and $p=0.00$, respectively).

Conclusion: We observed differences in clinical findings and prognoses between primary and metastatic brain tumor patients during the follow-up in PCC. Further to advances in treatment methods, we believe that identifying the need for palliative care and appropriate symptom management will improve the quality of life in brain tumor patients with poor prognosis.

Keywords: Brain tumors, palliative care, discharge status, seizure
Öz

Giriş: Erken Palyatif bakım müdahaleleri ve yapılandırılmış ileri bakım planlaması, beyin tümörü hastalarında semptom kontrolünü ve yaşam kalitesini artırabilir. Bu çalışmada palyatif bakım merkezimizde (PBM) primer ve metastatik beyin tümörü tanısı alan hastaların semptomlarını, çıkış durumlarını ve yatış sürelerini araştırmayı amaçladık.

Gereç ve Yöntem: Bu retrospektif çalışmada palyatif bakım servisinde primerve metastatik beyin tümörütanısı ile izlenen 91 hasta alındı. Çalışmaya alınan hastaların demografik özellikleri, glaskow koma skalası (GCS), Karnofsky Performans Skalası (KPS), çıkış durumu, hastanede yatış süresi ve semptomları karşılaştıııldı.

Bulgular: Hastaların yaş ortalaması 60,67 yıldı, \%59,3'ü erkekti ve yatış süreleri ortalama 29,26 gündü. Primer beyin tümörü olan hastalarda PEG, trakeostomi durumu ve nöbet, parezi semptomu oranları anlamlı derecede fazla idi $(p<0,05)$. Metastatik tümörü olanlarda ve GCS düşük olanlarda çııı̧ durumu exitus olanlar anlamlı derecede fazla idi $(p=0,032$, $p=0,00$ ).

Sonuç: Primer ve metastatik beyin tümörü olan hastaların palyatif bakımda izlemleri sırasında bulgularında ve klinik prognozlarında farklılılar olduğu gördük. Tedavilerdeki ilerlemelere rağmen zayıf prognoza sahip beyin tümörlerinin palyatif bakım intiyaçlarının belirlenip, semptomların iyi yönetilmesinin, bu hastalarda yaşam kalitesini artıracağını düşünüyoruz.

Anahtar Kelimeler: Beyin tümörleri, palyatif bakım, çııış durumu, nöbet

Corresponding (iletişim): Gülhan Sarıçam, Department of Neurology Clinic, Ankara Pursaklar State Hospital, Mimar Sinan Mah. Çağatay Sok. No:39 Ankara, Turkey

E-mail (E-posta): gulhansar01@hotmail.com

Received (Geliş Tarihi): 18.01.2021Ａccepted (Kabul Tarihi): 16.10.2021 


\section{INTRODUCTION}

Despite major advances in cancer therapeutics over the past decade, cancer patients continue to suffer from significant morbidity. Furthermore, mortality rates in cancer remain high. ${ }^{[1]}$ Brain tumors account for nearly $1.4 \%$ of all cancers. ${ }^{[2]}$ Malignant gliomas are tumors of glial origin, accounting for almost $70 \%$ of primary brain cancer diagnoses. Survival in malignant gliomas is less than two years. ${ }^{[3,4]}$ Cranial metastases are more common than primary brain tumors. Secondary brain tumors develop in $20-40 \%$ of systemic malignancies at a point in time during the disease course. ${ }^{[5]}$ With a mean survival of 1-6 months depending on the histology and the treatment applied, brain metastases significantly shorten the average life expectancy. ${ }^{[6]}$

Studies have shown that early integration of palliative care acts favorably on the quality of life, survival, mood of the patient, caregiver burden, and treatment. ${ }^{[7]}$ The life-limiting nature of gliomas and secondary brain tumors and the presence of specific symptoms due to neurological impairments require an early and multidisciplinary palliative care approach. ${ }^{[8,9]}$ Studies investigating whether differences exist in the palliative care needs of such patients are scarce and patients need to be evaluated more thoroughly in order for their specific needs to be addressed. ${ }^{[10]}$

In this study, we aimed to investigate the rates of percutaneous endoscopic gastrostomy (PEG), tracheostomy, pressure ulcers (PU); Glasgow Coma Scale (GCS) and Karnofsky Performance Scale (KPS) scores, and the effects of symptoms such as seizures, paresis, pain, and depression on the length of hospital stay (LOS) and discharge statuses in patients diagnosed with primary or metastatic brain tumors, who had been under follow-up in our palliative care center (PCC).

\section{MATERIAL AND METHOD}

This retrospective study was approved by the Ethics Committee of Dışkapı Yıldırım Beyazıt Training and Research Hospital (date: 06/04/2020; approval no: 85/03). All procedures were carried out in accordance with the principles of the Declaration of Helsinki. The files of 99 patients followed-up in our hospital's PCC with the diagnosis of a primary or metastatic brain tumor in the period between 1 January 2014 and 1 January 2020 were reviewed retrospectively. Eight patients; who had missing data in patient files and who had been hospitalized for one day or shorter, were excluded from the study. The symptoms observed in the patients were classified as pain, paresis, seizures, and depression. The ages and gender of the study patients; the presence of percutaneous endoscopic gastrostomy (PEG), tracheostomies, and pressure ulcers (PU); LOS in the hospital, the patient status at the time of hospital discharge [to home or to the intensive care unit (ICU) or the patient's death in the hospital], and symptoms (seizure, paresis, pain, and depression) of the patients included in the study were compared.
The diagnosis of depression was made by a psychiatrist according to the criteria of the classification of psychiatric disorders, the Diagnostic and Statistical Manual of Mental Disorders (DSM-IV). ${ }^{[1]}$ The severity of pain was evaluated using the Visual Analogue Scale (VAS). ${ }^{[12]}$ VAS is a continuous scale comprising a horizontal or a vertical line, usually 10 centimeters $(100 \mathrm{~mm})$ in length. Patients with a VAS score between 0 and $2 \mathrm{~cm}$ were considered pain-free. ${ }^{[13]}$

GCS was used for neurological evaluation and determining the consciousness level of the patient. GCS is evaluated according to the verbal response, motor response, and the eye-opening reaction of the patient. A calculated total score of 15 indicates the best response, whereas a score of 3 indicates the poorest response that can be obtained from the patient. ${ }^{[14]}$ The Karnofsky performance scale was used to rate functional impairment in the study patients. ${ }^{[15,16]}$ The Karnofsky performance scale scores range from 0 to 100 . A score between 80 and 100 indicates that the patient is able to carry on normal activities; a score between 50 and 70 indicates that the patient is unable to work but can meet most of the personal needs, and a score between 0 and 40 indicates that the patient is unable to carry on self-care.

\section{Statistical Analysis}

The study data were transferred to the SPSS Statistics 23 package program to perform the statistical analyses. Data were summarized as frequencies (numbers and percentages) for the categorical variables. Descriptive statistics (mean, standard deviation, median, minimum, and maximum) were used for the numerical variables. The Kolmogorov-Smirnov normality analysis revealed that the numerical variables did not conform to a normal distribution. For this reason, nonparametric statistical methods were used in the study. The differences between two independent groups were assessed by the Mann-Whitney $\mathrm{U}$ analysis. The Kruskal-Wallis analysis was used to evaluate the differences between more than two independent groups. The relationships between two independent categorical variables were assessed using the Chi-Square analysis. The relationships between two independent numerical variables were interpreted using Spearman's rho correlation coefficient. A value of 0.05 was considered to indicate statistical significance.

\section{RESULTS}

Eight patients; who had incomplete records and who had been hospitalized for one day or for a shorter period, were excluded from the study. A total of 91 patients; of which 37 (40.7\%) were women and 54 (59.3\%) were men, were included in the study. The mean age of the patients was 60.67 years and the mean LOS was 29.26 days. Of the patients; $69.2 \%$ had a primary brain tumor, $30.8 \%$ had a metastatic brain tumor, $56 \%$ had a PEG, $46.2 \%$ had a tracheostomy, and $51.6 \%$ had PU. Death occurred in $51.6 \%$ of the patients; $30.8 \%$ of the patients were discharged to home, and $17.6 \%$ of the patients were transferred to ICU. Seizures, paresis, pain, and depression 
were found in $80.2 \%, 78 \%, 64.8 \%$, and $34.1 \%$ of the patients, respectively. The mean GCS score of the patients was 8 . The mean KPS score was $10-40$ points in $82(90.1 \%)$ patients and 50-70 points in 9 (9.9\%) patients (Table 1 ).

Having a primary or metastatic brain tumor was statistically significantly associated with age, the presence of a PEG, tracheostomy, or PU; and the presence of paresis or seizure symptoms $(p<0.05)$. The age of the patients with a metastatic brain tumor was significantly higher compared to primary brain tumor patients $(p=0.001)$. The rates of having a PEG, tracheostomy, and $\mathrm{PU}$, and having paresis or seizures were significantly higher in primary brain tumor patients compared to metastatic brain tumor patients (Table 2).

\section{Table 1. Demographic characteristics of patients}

\begin{tabular}{|c|c|c|}
\hline$(n=91)$ & $\begin{array}{c}\text { Mean } \pm \text { standard } \\
\text { deviation }\end{array}$ & Median (Min.-Max.) \\
\hline Age (Year) & $60.67 \pm 13.528$ & $60.0(36.0-98.0)$ \\
\hline Length of Stay (Days) & $29.26 \pm 25.870$ & $22.0(6.0-180.0)$ \\
\hline \multirow[t]{2}{*}{ GCS } & $7.69 \pm 1.787$ & $8.0(4.0-12.0)$ \\
\hline & Number & $\%$ \\
\hline \multicolumn{3}{|l|}{ Gender } \\
\hline Female & 37 & 40.7 \\
\hline Male & 54 & 59.3 \\
\hline \multicolumn{3}{|l|}{ PEG } \\
\hline Yes & 51 & 56.0 \\
\hline No & 40 & 44.0 \\
\hline \multicolumn{3}{|l|}{ Tracheostomy } \\
\hline Yes & 42 & 46.2 \\
\hline No & 49 & 53.8 \\
\hline \multicolumn{3}{|l|}{ PU } \\
\hline Yes & 47 & 51.6 \\
\hline No & 44 & 48.4 \\
\hline \multicolumn{3}{|l|}{ Discharge Status } \\
\hline Home & 28 & 30.8 \\
\hline Exitus & 47 & 51.6 \\
\hline ICU & 16 & 17.6 \\
\hline \multicolumn{3}{|l|}{ Pain } \\
\hline Yes & 59 & 64.8 \\
\hline No & 32 & 35.2 \\
\hline \multicolumn{3}{|l|}{ Paresis } \\
\hline Yes & 71 & 78.0 \\
\hline No & 20 & 22.0 \\
\hline \multicolumn{3}{|l|}{ Seizure } \\
\hline Yes & 73 & 80.2 \\
\hline No & 18 & 19.8 \\
\hline \multicolumn{3}{|l|}{ Depression } \\
\hline Yes & 31 & 34.1 \\
\hline No & 60 & 65.9 \\
\hline \multicolumn{3}{|l|}{ Tumor } \\
\hline Primary & 63 & 69.2 \\
\hline Metastatic & 28 & 30.8 \\
\hline \multicolumn{3}{|l|}{ KPS } \\
\hline $10-40$ & 82 & 90,1 \\
\hline $50-70$ & 9 & 9,9 \\
\hline
\end{tabular}

ICU: Intensive care unit, PEG: Percutaneous endoscopic gastrostomy, PU: Pressure ulcers, GCS Glasgow Coma Scale, KPS: Karnofsky Performance Scale
Table 2. Examination of the relationship between tumors and variables

\begin{tabular}{|c|c|c|c|c|c|c|}
\hline \multirow{5}{*}{$\begin{array}{l}\text { Age (Year) } \\
\text { GCS }\end{array}$} & \multirow{2}{*}{\multicolumn{2}{|c|}{$\begin{array}{c}\text { Primary Tumor } \\
\begin{array}{c}\text { Median } \\
\text { (Min.-Max.) }\end{array}\end{array}$}} & \multirow{2}{*}{\multicolumn{2}{|c|}{$\begin{array}{c}\text { Metastatic Tumor } \\
\text { Median } \\
\text { (Min.-Max.) }\end{array}$}} & \multirow[b]{2}{*}{ Z } & \multirow[b]{2}{*}{$\mathbf{p}$} \\
\hline & & & & & & \\
\hline & \multicolumn{2}{|c|}{$55(36-88)$} & \multicolumn{2}{|c|}{68 (39-98) } & -3.429 & $0.001 *$ \\
\hline & \multicolumn{2}{|c|}{$8(4-12)$} & \multicolumn{2}{|c|}{$7(5-11)$} & -1.442 & 0.149 \\
\hline & Number & $\%$ & Number & $\%$ & $\mathbf{X} 2$ & $\mathbf{p}$ \\
\hline \multicolumn{7}{|l|}{ Gender } \\
\hline Female & 24 & 64.9 & 13 & 35.1 & 0.558 & 0.455 \\
\hline Male & 39 & 72.2 & 15 & 27.8 & & \\
\hline \multicolumn{7}{|l|}{ PEG } \\
\hline Yes & 43 & 84.3 & 8 & 15.7 & 12.391 & $0.000^{*}$ \\
\hline No & 20 & 50.0 & 20 & 50.0 & & \\
\hline \multicolumn{7}{|c|}{ Tracheostomy } \\
\hline Yes & 35 & 83.3 & 7 & 16.7 & 7.282 & $0.007^{*}$ \\
\hline No & 28 & 57.1 & 21 & 42.9 & & \\
\hline \multicolumn{7}{|l|}{ PU } \\
\hline Yes & 41 & 87.2 & 6 & 12.8 & 14.790 & $0.000^{*}$ \\
\hline No & 22 & 50.0 & 22 & 50.0 & & \\
\hline \multicolumn{7}{|l|}{ Pain } \\
\hline Yes & 40 & 67.8 & 19 & 32.2 & 0.162 & 0.687 \\
\hline No & 23 & 71.9 & 9 & 28.1 & & \\
\hline \multicolumn{7}{|l|}{ Paresis } \\
\hline Yes & 59 & 83.1 & 12 & 16.9 & 29.166 & $0.000^{*}$ \\
\hline No & 4 & 20.0 & 16 & 80.0 & & \\
\hline \multicolumn{7}{|l|}{ Seizure } \\
\hline Yes & 59 & 80.8 & 14 & 19.2 & 23.277 & $0.000^{*}$ \\
\hline No & 4 & 22.2 & 14 & 77.8 & & \\
\hline \multicolumn{7}{|c|}{ Depression } \\
\hline Yes & 18 & 58.1 & 13 & 41.9 & 2.752 & 0.097 \\
\hline No & 45 & 75.0 & 15 & 25.0 & & \\
\hline \multicolumn{7}{|l|}{ KPS } \\
\hline $10-40$ & 55 & 67.1 & 27 & 32.9 & 1.812 & 0.178 \\
\hline $50-70$ & 8 & 88.9 & 1 & 11.1 & & \\
\hline
\end{tabular}

LOS was statistically significantly associated with the presence of a PEG, tracheostomy, or PU; the PCC discharge status and the presence of paresis or seizures $(p<0.05)$. LOS was significantly longer in patients without a PEG, tracheostomy, or PU. LOS was significantly long in metastatic tumor patients and in patients having no seizures. LOS was significantly higher in patients; who had died in the hospital, compared to patients discharged to home $(p=0.039)$. A negative and lowlevel statistically significant relationship was found between age and LOS (Table $\mathbf{3}$ ).

The hospital discharge status was statistically significantly associated with the presence of primary or metastatic brain tumors and GCS scores $(p<0.05)$. While significantly more patients with primary brain tumors were discharged to home, the mortality rate was significantly higher in patients with metastatic brain tumors. The mortality rate was significantly high in patients with low GCS scores (Table 4). 
Table 3. Examination of the relationship between the length of stay and variables

\begin{tabular}{|c|c|c|c|c|}
\hline \multirow{3}{*}{ Gender } & \multicolumn{2}{|c|}{$\begin{array}{c}\text { Length of } \\
\text { hospitalization }\end{array}$} & \multirow{2}{*}{$\begin{array}{l}\text { Statistical } \\
\text { Analysis }\end{array}$} & \multirow{2}{*}{$\mathbf{p}$} \\
\hline & \multirow[t]{2}{*}{ Number } & \multirow[t]{2}{*}{$\begin{array}{c}\text { Median } \\
\text { (Min.-Max.) }\end{array}$} & & \\
\hline & & & & \\
\hline Female & 37 & $58(36-90)$ & $Z=-1.093$ & 0.274 \\
\hline Male & 54 & $60(43-98)$ & & \\
\hline \multicolumn{5}{|l|}{ PEG } \\
\hline Yes & 51 & $55(36-98)$ & $Z=-2.216$ & $0.027^{*}$ \\
\hline No & 40 & $63,5(44-88)$ & & \\
\hline \multicolumn{5}{|c|}{ Tracheostomy } \\
\hline Yes & 42 & $53,5(36-75)$ & $Z=-2.980$ & $0.003 *$ \\
\hline No & 49 & $61(36-98)$ & & \\
\hline \multicolumn{5}{|l|}{ PU } \\
\hline Yes & 47 & $60(36-98)$ & $Z=-2.021$ & $0.043^{*}$ \\
\hline No & 44 & $59(36-90)$ & & \\
\hline \multicolumn{5}{|c|}{ Discharge Status } \\
\hline 1.Home & 28 & $53(36-88)$ & KWI- 601 & $0.039 *$ \\
\hline 2.Exitus & 47 & $63(36-98)$ & $K V=6.484$ & $\begin{array}{l}\text { Dirrerence: } \\
\text { EX-Home }\end{array}$ \\
\hline 3. ICU & 16 & $55(44-87)$ & & \\
\hline \multicolumn{5}{|l|}{ Pain } \\
\hline Yes & 59 & $57(36-98)$ & $Z=-1.129$ & 0.259 \\
\hline No & 32 & $63(39-87)$ & & \\
\hline \multicolumn{5}{|l|}{ Paresis } \\
\hline Yes & 71 & $59(36-98)$ & $Z=-0.634$ & 0,526 \\
\hline No & 20 & $62,5(36-87)$ & & \\
\hline \multicolumn{5}{|l|}{ Seizure } \\
\hline Yes & 73 & $55(36-98)$ & $Z=-2.621$ & $0.009^{*}$ \\
\hline No & 18 & $64(36-90)$ & & \\
\hline \multicolumn{5}{|l|}{ Depression } \\
\hline Yes & 31 & $60(36-98)$ & $Z=-0.206$ & 0.837 \\
\hline No & 60 & $59,5(36-90)$ & & \\
\hline \multicolumn{5}{|l|}{ Tumor } \\
\hline Primary & 63 & $55(36-88)$ & $Z=-2.081$ & $0.037^{*}$ \\
\hline Metastatic & 28 & 68 (39-98) & & \\
\hline \multicolumn{5}{|l|}{ KPS } \\
\hline $10-40$ & 82 & $21.5(6-180)$ & $Z=-0.726$ & 0.468 \\
\hline \multirow[t]{2}{*}{$50-70$} & 9 & $24(10-56)$ & & \\
\hline & Number & $\mathbf{r}$ & p & \\
\hline Age & 91 & -0.231 & $0.028^{*}$ & \\
\hline GCS & 91 & 0.131 & 0.215 & \\
\hline
\end{tabular}

Z: Mann Whitney U KW: Kruskal Wallis *: $p<0.05$ r: Spearman's Rho Correlation Coefficient. PEG: Percutaneous endoscopic gastrostomy, PU: Pressure ulcers, GCS: Glasgow Coma Scale, KPS: KEG: Percutaneous endoscopic

\section{DISCUSSION}

The life-limiting nature of primary brain tumors and the presence of specific symptoms due to neurological impairment require an early and appropriate palliative care approach. ${ }^{[17]}$ Brain metastases are the most common cerebral malignancies, in which most of the symptoms occur due to direct brain compression caused by the tumor or edema. Palliative care has an essential role in approaching patients with brain metastasis and managing their symptoms ${ }^{[9]}$ Of the patients followed-up in our palliative care center; $69.2 \%$ had been diagnosed with primary brain tumors and $30.8 \%$ had been diagnosed with metastatic brain tumors. The mean age of the patients was 60.67 years; $59.3 \%$ of the patients were men, and the mean LOS was 29.26 days.

Studies have documented the potential value of PEG tube placement in patients with nutritional and swallowing problems such as those with head and neck cancer. In patients with cancer, enteral tube feeding is often required due to dysphagia, odynophagia, side effects during or after treatment, dehydration, and weight loss. ${ }^{[18]}$ There is very little research on PEG placement in patients with brain tumors receiving palliative care. ${ }^{[19]}$ The use of tracheostomy during the palliative care process in cancer patients aims to relieve symptoms, provide comfort, facilitate daily life activities, and achieve long-term optimization survival period. ${ }^{[20]}$ In our study, the rates of tracheostomy (83.3\%) and PEG (84.3\%) were significantly high in patients with primary brain tumors. We thought that such high rates of tracheostomy and PEG could be explained by the longer-term survival of primary brain tumor patients compared to patients with metastatic brain tumors. The study by Jakobsen et al. ${ }^{[21]}$ demonstrated that advanced age, proximity to death, long hospital stays, and a poor clinical condition increased the risk of PU development. In our study, PU was significantly more common in patients diagnosed with primary brain tumors compared to patients with metastatic brain tumors. We thought that this finding could result from the high rate of paresis, higher rates of discharge to home despite a longer hospital stay, and the longer survival of patients with primary brain tumors compared to metastatic tumor patients.

The clinical findings of brain tumors depend on the location, histological type, and size of the tumor. Typical symptoms include increased intracranial pressure and focal neurological findings. Seizures are frequent complications occurring in $70 \%$ of primary brain tumor patients and in $40 \%$ of patients with brain metastases. ${ }^{[22]}$ Consistent with our study, Ostgathe et al. ${ }^{[23]}$ found out that the symptoms of paresis and seizures were more frequent in primary brain tumors than metastatic brain tumors. It is estimated that $50 \%$ of patients with brain tumors have depressive symptoms. ${ }^{[24]}$ In our study, we identified depression in $34.1 \%$ and pain in $64.8 \%$ of the palliative care patients with primary or metastatic brain tumors; however, we did not detect a statistically significant difference between the two groups.

It has been demonstrated in the literature that the mortality rate is higher in metastatic brain tumor patients compared to patients with primary brain tumors and other palliative care patients. ${ }^{[23]}$ The prognosis of metastatic brain tumors is poor and the average survival is 6-12 months. ${ }^{[25]}$ Similarly, the mortality rate was significantly high and the length of hospital stay was long in metastatic brain tumor patients in our study. We think that the poor clinical condition of these patients prolonged their stay in palliative care. It has been previously shown that low GCS scores are associated with a long LOS and a close proximity to death in serious diseases and injuries. ${ }^{[26]}$ 
Table 4. Examination of the relationship between discharge condition and variables

\begin{tabular}{|c|c|c|c|c|c|c|c|c|}
\hline & \multicolumn{6}{|c|}{ Discharge Status } & \multirow{3}{*}{ K.W. } & \multirow{3}{*}{$\mathbf{p}$} \\
\hline & \multicolumn{2}{|c|}{ 1.Home } & \multicolumn{2}{|c|}{ 2.EX } & \multicolumn{2}{|c|}{ 3. ICU } & & \\
\hline & \multicolumn{2}{|c|}{ Median (Min.-Max.) } & \multicolumn{2}{|c|}{ Median (Min.-Max.) } & \multicolumn{2}{|c|}{ Median (Min.-Max.) } & & \\
\hline Age (Year) & \multicolumn{2}{|c|}{$53(36-88)$} & \multicolumn{2}{|c|}{$63(36-98)$} & \multicolumn{2}{|c|}{$55(44-87)$} & 4.205 & 0.122 \\
\hline \multirow[t]{2}{*}{ GCS } & \multicolumn{2}{|c|}{$9(6-12)$} & \multicolumn{2}{|c|}{$7(4-10)$} & \multicolumn{2}{|c|}{$8(7-11)$} & 30.124 & $\begin{array}{c}0.000^{*} \\
\text { Difference: } 2-1,3\end{array}$ \\
\hline & Number & $\%$ & Number & $\%$ & Number & $\%$ & $\mathbf{X} 2$ & $\mathbf{p}$ \\
\hline \multicolumn{9}{|l|}{ Gender } \\
\hline Female & 15 & 40.5 & 17 & 45.9 & 5 & 13.5 & 2.914 & 0.233 \\
\hline Male & 13 & 24.1 & 30 & 55.6 & 11 & 20.4 & & \\
\hline \multicolumn{9}{|l|}{ PEG } \\
\hline Yes & 18 & 35.3 & 22 & 43.1 & 11 & 21.6 & 3.448 & 0.178 \\
\hline No & 10 & 25.0 & 25 & 62.5 & 5 & 12.5 & & \\
\hline \multicolumn{9}{|c|}{ Tracheostomy } \\
\hline Yes & 18 & 42.9 & 18 & 42.9 & 6 & 14.3 & 5.353 & 0.069 \\
\hline No & 10 & 20.4 & 29 & 59.2 & 10 & 20.4 & & \\
\hline \multicolumn{9}{|l|}{ PU } \\
\hline Yes & 14 & 29.8 & 25 & 53.2 & 8 & 17.0 & 0.093 & 0.955 \\
\hline No & 14 & 31.8 & 22 & 50.0 & 8 & 18.2 & & \\
\hline \multicolumn{9}{|l|}{ Pain } \\
\hline Yes & 14 & 23.7 & 33 & 55.9 & 12 & 20.3 & 4.024 & 0.134 \\
\hline No & 14 & 43.8 & 14 & 43.8 & 4 & 12.5 & & \\
\hline \multicolumn{9}{|l|}{ Paresis } \\
\hline Yes & 21 & 29.6 & 37 & 52.1 & 13 & 18.3 & 0.260 & 0.878 \\
\hline No & 7 & 35.0 & 10 & 50.0 & 3 & 15.0 & & \\
\hline \multicolumn{9}{|l|}{ Seizure } \\
\hline Yes & 26 & 35.6 & 34 & 46.6 & 13 & 17.8 & 4.668 & 0.097 \\
\hline No & 2 & 11.1 & 13 & 72.2 & 3 & 16.7 & & \\
\hline \multicolumn{9}{|l|}{ Depression } \\
\hline Yes & 11 & 35.5 & 18 & 58.1 & 2 & 6.5 & 4.027 & 0.133 \\
\hline No & 17 & 28.3 & 29 & 48.3 & 14 & 23.3 & & \\
\hline \multicolumn{9}{|l|}{ Tumor } \\
\hline Primary & 24 & $38.1 a$ & 27 & $42.9 a$ & 12 & $19.0 \mathrm{a}$ & 6.885 & $0.032^{*}$ \\
\hline Metastatic & 4 & $14.3 b$ & 20 & $71.4 \mathrm{~b}$ & 4 & $14.3 a$ & & \\
\hline \multicolumn{9}{|l|}{ KPS } \\
\hline $10-40$ & 19 & 23.2 & 47 & 57.3 & 16 & 19.5 & - & - \\
\hline $50-70$ & 9 & 100.0 & 0 & 0.0 & 0 & 0.0 & 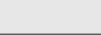 & 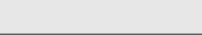 \\
\hline
\end{tabular}

K.W.: Kruskal Wallis X2: Chi-Square Analysis * : p<0.05. PEG: Percutaneous endoscopic gastrostomy, PU: Pressure ulcers, GCS: Glasgow Coma Scale, KPS: Karnofsky Performance Scale

In our study, we found that the mortality rate was significantly high in patients with low GCS. Although studies have shown that performance status is an independent predictor of survival in patients with cancer, no significant relationship was found between KPS and LOS or discharge status in our study. [27]

Our study had limitations such as the small number of patients and the lack of a control group.

\section{CONCLUSION}

In our study, we observed that there were differences in the findings and clinical prognoses in patients with primary and secondary brain tumors during the follow-up in palliative care. In patients with primary brain tumors, the rates of having a PEG, a tracheostomy, seizures, and paresis symptoms were significantly high. While mortality was significantly high in patients with metastatic tumors and low GCS scores, the rate of "discharged to home" status was significantly high in patients with primary brain tumors. Further to advances in treatment, we are of the opinion that identifying palliative care needs and providing appropriate symptom management will improve the quality of life in brain tumor patients with poor prognosis.

\section{ETHICAL DECLARATIONS}

Ethics Committee Approval: The study was carried out with the permission of Dışkapı Yıldırım Beyazıt Training and Research Hospital Ethics Committee (Date: 06/04/2020, Decision No: 85/03). 
Informed Consent: Because the study was designed retrospectively, no written informed consent form was obtained from patients.

Referee Evaluation Process: Externally peer-reviewed.

Conflict of Interest Statement: The authors have no conflicts of interest to declare.

Financial Disclosure: The authors declared that this study has received no financial support.

Author Contributions: All of the authors declare that they have all participated in the design, execution, and analysis of the paper, and that they have approved the final version.

\section{REFERENCES}

1. Siegel RL, Miller KD, Jemal A. Cancer statistics, 2018. CA Cancer J Clin 2018;68(1):7-30.

2. Lyon JG, Mokarram N, Saxena T, Carroll SL, Bellamkonda RV. Engineering Challenges for Brain Tumor Immunotherapy. Adv Drug Deliv Rev 2017;114:19-32.

3. Wen PY, Kesari S. Malignant gliomas in adults. N Engl J Med 2008;359:492507.

4. Stupp R, Mason WP, Van Den Bent MJ, et al. Radiotherapy plus concomitant and adjuvant temozolomide for glioblastoma. N Engl J Med 2005;352(10):987-96

5. Taillibert S, Delattre JY. Palliative care in patients with brain metastases. Curr Opin Oncol 2005;17(6):588-92.

6. Pease NJ, Edwards A, Moss LJ. Effectiveness of whole brain radiotherapy in the treatment of brain metastases: a systematic review. Palliat Med 2005;19(4):288-99.

7. Golla $\mathrm{H}$, Nettekoven $\mathrm{C}$, Bausewein $\mathrm{C}$, et al. Effect of early palliative care for patients with glioblastoma (EPCOG): a randomised phase III clinical trial protocol. BMJ Open 2020;10(1): e034378.

8. Pace A, Dirven L, Koekkoek JAF, et al. European Association for NeuroOncology (EANO) guidelines for palliative care in adults with glioma. Lancet Oncol 2017;18(6):330-40.

9. Noh T, Walbert T. Brain metastasis: clinical manifestations, symptom management, and palliative care. Handb Clin Neurol 2018;149:75-88.

10. Ayling OGS, Goldman R, Bernstein M. Glioblastoma, the Neurosurgeon, and Neuro-Palliative Care. Handb Clin Neurol 2018;149:75-88.

11. American Psychiatric Association, Diagnostic and Statistical Manual of Mental Disorders, 19944th edition Washington, DC American Psychiatric Association.

12. Mc Cormack HM, Horne DJ, Sheather S. Clinical applications of visual analogue scales: a critical review. Psychol Med 1988;18:1007-19.

13. Aicher B, Peil H, Peil B, Diener H-C. Pain measurement: Visual Analogue Scale (VAS) and Verbal Rating Scale (VRS) in clinical trials with OTC analgesics in headache. Cephalalgia 2012;32(3):185-97.

14. Teasdale G. Jennet B. Assesment of coma and impaired consicousness: A practical scale. Lancet 1974;2(7872):81-4.

15. Çeltek NY, Süren M, Demir O, Okan I. Karnofsky Performance Scale validity and reliability of Turkish palliative cancer patients. Turk J Med Sci. 2019; 49:894-8

16. Aras M, Delialioğlu ÜS, Atalay N, Selçuk ST. Kanser hastalarının rehabilitasyon gereksinimi. Türk Fiz Tıp Rehab Derg 2009;55(3):25-9.

17. Hemminger LE, Pittman CA, Korones DN, et al. Palliative and end-of-life care in glioblastoma: defining and measuring opportunities to improve care. Neurooncol Pract 2017;4(3):182-8.

18. Lucendo AJ, Friginal-Ruiz AB. Percutaneous endoscopic gastrostomy: An update on its indications, management, complications, and care. Rev Esp Enferm Dig. 2014;106(8):529-39.
19. Schmidt E. [Percutaneous endoscopic gastrostomy-tube for a patient with glioblastoma to enable his admission into a nursing home]. Wien Med Wochenschr. 2010;160(13-14):328-30.

20. Chan T, Devaiah AK. Tracheostomy in palliative care. Otolaryngol Clin North Am. 2009;42(1):133-41.

21. Jakobsen TBT, Pittureri $C$, Seganti $P$, et al. Incidence and prevalence of pressure ulcers in cancer patients admitted to hospice: A multicentre prospective cohort study. Int Wound J 2020;17(3):641-9.

22. Alajbegović A, Loga N, Alajbegović S, Suljić E. Characteristics of symptomatic epilepsy in patients with brain tumours. Bosn J Basic Med Sci. 2009;9(1):81-4.

23. Ostgathe C, Gaertner J, Kotterba M, et al. Differential palliative care issues in patients with primary and secondary brain tumours. Support Care Cancer 2010;18(9):1157-63.

24. Pranckeviciene A, Bunevicius A. Depression screening in patients with brain tumors: a review. CNS oncology 2015;4(2):71-8.

25. Soffiettia R, Cornub P, Delattrec JY, et al. EFNS guidelines on diagnosis and treatment of brain metastases: report of an EFNS Task Force, Eur J Neurol 2006;13:674-81.

26. Clark DE, Ryan LM. Concurrent Prediction of Hospital Mortality and Length of Stay from Risk Factors on Admission. Health Serv Res 2002;37(3):63145.

27. Boland JW, Allgar V, Boland EG, Kaasa S, Hjermstad MJ, Johnson MJ. Predictors and trajectory of performance status in patients with advanced cancer: A secondary data analysis of the international European Palliative Care Cancer Symptom study. Palliat Med 2019;33(2):206-12. 